\title{
Note on New or Rare British Marine Polyzoa.
}

\author{
By
}

S. F. Harmer, M.A., B.Sc.

\section{Hypophorella expansa, Ehlers.}

Hypophorella expansa, Ehlers, Abh. Ges. Götting., xxi., 1876, Phys. Cl., 1; Prouho, Arch. Zool. Exp. (2), x., 1892, p. 594.

Delagia chatopteri, Joyeux-Laffuie, C. R. Ac. Sci., cvi., 1888, p. 620, and Arch. Zool. Exp. (2), vi., 1888, p. 135.

THIS species was originally found by Ehlers at Spiekeroog, an island off the coast of E. Friesland, in the North Sea. It has more recently been found by Joyeux-Laffuie at Luc-sur-Mer (Normandy), and by Prouho at Roscoff and at Banyuls. Its wide distribution, from the North Sea to the Mediterranean, made it almost certain that it would be found in British waters when looked for in the right place. Ehlers discovered it in the substance of the tubes of Terebella (Lanice) conchilega, while Joyeux-Laffuie and Prouho found it in the tubes of Chatopterus.

On one of the last days of my stay at Plymouth in April last, a few Choetopterus tubes, dredged near the Eddystone in thirty fathoms, were brought to the Laboratory. Several of these tubes contained Hypophorella expansa, which I had no difficulty in finding by following the directions given by Joyeux-Laffuie. The tube should be slit open, and a thin lamella of its substance, stripped off from the inner side, should be examined with the microscope. Even if the delicate zocecia are torn by the operation, or if the lamella be too thin to include any zocecia, the presence of the Polyzoon may be recognized by the holes through which the tentacles can be protruded into the interior of the tube. Each of these holes appears to the naked eye as a minute, opaque, white spot. The spotted appearance of the inside of the tube is a convenient indication of the presence of the Hypophorella, which can at once be recognized by the very long, thread-like connexions between the zoccia, and by the two curious vesicular cavities which occur, one on either side of the distal end of the zocecium. Excellent figures of 
the species are given by Ehlers and by Joyeux-Laffuie in his second paper.* Prouho's account contains some interesting details with regard to the mechanism of burrowing in the tube of the host, and with regard to the character of the larva, which, as Prouho has shown, belongs to the Cyphonautes type.

Hypophorella is probably common wherever Chcetopterus occurs. I have not made any careful examination of the tubes of Terebella conchilega, but it may be worth while to point out that Ehlers discovered the Polyzoon most commonly in the parts of the tube which do not project above the surface of the sand.

\section{Escharoides quincuncialis, Norman.}

The history of this species, which was described from a single fragment, not more than a quarter of an inch long, is given on p. 339 of Hincks' British Marine Polyzoa (1880). The original specimen came from deep water in the Minch.

I obtained a single piece, closely resembling Dr. Norman's specimen, in April, 1889. The fragment was dredged off Plymouth, but I am not able to give either the exact locality or the depth from which it was obtained. The specimen was mounted in glycerine-jelly, which has unfortunately completely decalcified it, but from my examination of it, made in 1889 , I can state that its agreement with the original description was very close.

\section{Micropora complanata, Norman.}

Lepralia complanata, Norman, Ann. Nat. Hist. (3), xiii., 1864, p 85; Hincks, Ibid. (5), xix., 1887, p. 304.

Micropora complanata, Hincks, Brit. Mar. Polyzoa, 1880, p. 175.

Membranipora smittii, Manzoni, SB. Ak. Wien, lxi , 1 Abth., 1870, p. 333.

Dr. Norman's original specimens were from Mr. Barlee's collection; and although they were believed to be British, their locality was unknown. Hincks (1887) has described specimens from the Adriatic, and Manzoni (1870) had previously found the same species in the Pliocene of Calabria. I believe I am correct in saying that no British localities have yet been recorded.

I found this species on the north-east side of the island of Tresco (Scilly Isles) in the spring of 1895 . It occurred commonly as large white encrustations on the sheltered surfaces of the granite rocks exposed between tide-marks. The empty Lamellibranch valves on which Laminaria picked up on the shore had grown also afforded one or two specimens. Dr. Norman kindly verified my determination, and suggested to me that this is a southern species which only just

$$
\text { * Arch, Zool. Exp. (2), vi. pl, viii. }
$$


reaches our shores. Although I believe it to be one of the commonest littoral forms in Scilly, I have not found it at Plymouth.

Mr. Hincks, in his later reference to this species (1887), refers it to the genus Lepralia. He there states that the "marginal callosity," described by Manzoni (pl. iii. fig. 16), in the specimens from the Italian Tertiaries, is well developed in the specimens from the Adriatic, but that "there is scarcely a trace of it in British examples." This statement is not confirmed by my specimens from Scilly, in which the marginal callosities are at least as well developed, in many of the zoœcia, as in those figured by Manzoni.

4. Schizoporella cristata, Hincks. (See Brit. Mar. Polyzoa, 1880, p. 254.)

This is a species described by Mr. Hincks from a single small colony found at Hastings. It is of some interest to record the discovery of two similar small colonies on the inside of an empty valve of Pecten maximus, from twenty fathoms on the Mewstone Ledge at Plymouth. 